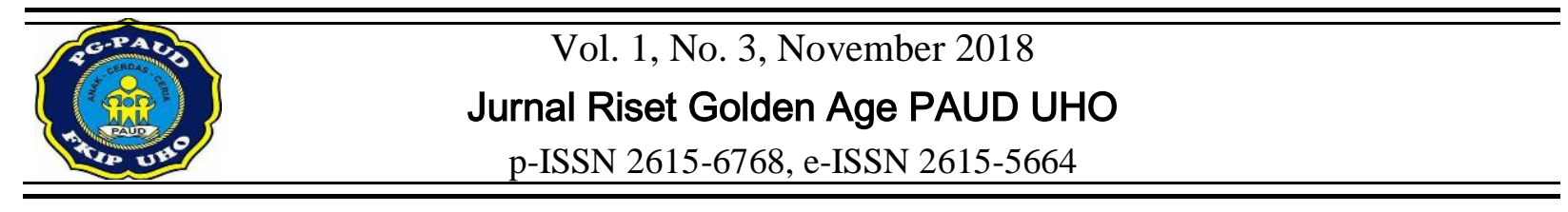

\title{
MENINGKATKAN KEMAMPUAN ANAK MENGENAL LAMBANG BILANGAN MELALUI MEDIA PAPAN FLANEL
}

\author{
Netty Angraeni 1), Arvyaty ${ }^{2)}$, Salim 2) \\ ${ }^{1}$ Jurusan PG-PAUD, Universitas Halu Oleo. Jln. H.E.A Mokodompit, Kendari 93232, Indonesia. \\ ${ }^{2} J u r u s a n$ Pendidikan Matematika, Universitas Halu Oleo. Jln. H.E.A Mokodompit, Kendari 93232, \\ Indonesia.
}

\begin{abstract}
Abstrak
Penelitian ini bertujuan untuk meningkatkan kemampuan anak mengenal lambang bilangan melalui media papan flanel di kelompok A RA' Budi Rahma Kendari. Penelitian ini adalah Penelitian Tindakan Kelas (PTK). Subjek dalam penelitian ini adalah guru dan anak Kelompok ARA Budi Rahmah Kendariyang berjumlah 16 orang yang terdiri atas 7 orang anak laki-laki dan 9 orang anak perempuan. Penelitian ini dilaksanakan dalam dua siklus. Tahap-tahap dalam penelitian mengikuti prosedur Penelitian Tindakan kelas, yaitu: (1) perencanaan, (2) pelaksanaan, (3) pengamatan atau observasi, dan (4) refleksi. Berdasarkan hasil tentang kemampuan anak mengenal lambang bilangan melalui media papan flanel menunjukkan bahwa terdapat peningkatan. Hal ini dapat dibuktikan pada hasil observasi awal diperoleh persentase $31 \%$, pada siklus I diperoleh persentase 56\%, dan pada siklus II di peroleh persentase ketuntasan $81 \%$. Dengan demikian dapat disimpulkan bahwa kemampuan anak menegenal lambang bilangan di Kelompok A RA Budi Rahmah Kendari dapat ditingkatkan melalui media papan flanel.
\end{abstract}

Keywords: Kemampuan, Lambang Bilangan, Media Papan Flanel

\section{IMPROVING CHILDREN'S ABILITIES TO KNOW THE SYMBOL OF NUMBERS THROUGH THE MEDIA OF FLANNEL BOARD}

\begin{abstract}
This study aims to improve the ability of children to recognize the number symbols through flannel board media in group A RA 'Budi Rahma Kendari. This type of research is Classroom Action Research (PTK). Subjects in this study were teachers and children of Group A RA 'Budi Rahma Kendari consisting of 16 people consisting of 7 boys and 9 girls. This study was conducted in two cycles. The stages in the study follow the classroom Action Research procedure, namely: (1) planning, (2) implementation, (3) observation or observation, and (4) reflection. Based on the results of the child's ability to recognize the number symbol through the flanel board media shows that there is an increase. This can be proven on the results of preliminary observations obtained $31 \%$ percentage, in the first cycle obtained $56 \%$ percentage, and on the second cycle in obtaining the percentage of $81 \%$ mastery. Thus it can be concluded that the child's ability to recognize the number symbol in Group A $R A$ 'Budi Rahma Kendari can be improved through flannel board media.
\end{abstract}

Keyword: Capability, Number Coat, Media Board Flannel

\section{PENDAHULUAN}

Pendidikan pada jalur formal pada umumya ada RA Budi Rahmah Kendari dan TK (Taman Kanak-kanak), biasanya pada rentan usia 4-5 tahun. Pada usia Taman Kanakkanak(4-5 tahun) merupakan tahap prasekolah untuk menuju usia sekolah. Didalam sekolah guru diharapkan menjadi fasilitator mengembangkan kemampuan anak baik kemampuan fisik/motorik halus, bahasa, kognitif, sosial emosional dan norma agama. Pada anak usia TK (4-5 tahun) berada pada tahap kognitif praoperasional. Pada anak usia 45 tahun atau TK kelompok A sudah dapat dikenalkan dengan lambang bilangan. 
Anak usia dini merupakan anak pada tahapan usia 0-6 tahun. Disebut anak usia dini karena pada masa itulah yang sangat menentukan bagi anak dalam mengembangkan potensinya. Usiausia seperti itulah sering disebut sebagai usia emas (the golden age). Maka dari itu pendidikan untuk anak usia dini merupakan pendidikan yang sangat penting dilakukan, karena dalam pendidikan tersebut merupakan dasar bagi pembentukan kepribadian manusia, sebagai peletak dasar budi pekerti luhur, kepandaian dan keterampilan.

Pendidikan pada jalur formal pada umumnya ada RA (Raudhatul Alfal) dan TK (Taman Kanak-kanak), biasanya pada rentan usia 4-5 tahun. Pada usia Taman Kanak-Kanak (4-5 tahun) merupakan tahap prasekolah untuk menuju usia sekolah. Di dalam sekolah guru di harapkan menjadi fasilitator dalam mengembangkan kemampuan anak baik dalam kemampuan fisik/ motorik halus, bahasa, kognitif, sosial emosional, dan norma agama. Anak usia TK (4-5 tahun) berada pada tahap kognitif praoperasional.Pada anak usia 4-5 tahun atau TK kelompok A sudah dapat dikenalkan dengan lambang bilangan.

Hal ini sudah sesuai dengan Peraturan Menteri Pendidikan Nasional Republik Indonesia Nomer 58 Tahun 2009 berkaitan dengan konsep bilangan dan huruf, bahwa anak usia 4-5 tahun diharapkan mampu mencapai tingkat pencapaian perkembangan diantaranya, mengetahui konsep banyak dan sedikit membilang banyak benda satau sampai sepuluh, mengenal konsep bilangan, mengenal lambang bilangan.

Adapun dalam kurikulum TK tahun 2004 tentang pengenalan lambang bilangan pada anak kelompok A usia 4-5 tahun, tingkat pencapaian perkembangan mengenal bilangan terdiri atas indikator menunjuk lambang bilangan 1-10, meniru lambang bilangan 1-10, menghubungkan atau memasangkan lambang bilangan dengan benda-benda sampai 10 (anak tidak disuruh menulis).

Menurut Piaget dalam Susanto (2011: 100) ada tiga tahapan dalam mengenalkan bilangan yaitu, tahap penguasaan konsep/ pengertian.Dalam hal ini anak membutuhkan bimbingan guru untuk menghitung. Pelaksanaan proses pembelajaran matematika di Taman Kanak-kanak (TK) harus memahami dan menggunakan media sebagai alat bantu. Pengajaran matematika harus dibuat ke dalam contoh-contoh atau benda nyata agar anak lebih mudah memahaminya, karena mengingat perkembangan anak pada masa ini berada pada masa konkret. Maka dari itu, pendidik dituntut untuk harus kreatif dalam menyajikan pembelajaran yang menarik untuk semua pembelajaran. Anak tidak hanya disuruh menulis saja namun juga harus tersedia media yang menarik agar anak tertarik dengan pembelajaran mengenal bilangan.

Menurut Sudaryanti (2006: 1) untuk menyatakan suatu bilangan dinotasikan dengan lambang bilangan yang disebut angka. Untuk menyatakan bilangan suatu lambang atau simbol yang disebut dengan angka. Menurut pengertiannya, antara bilangan dengan lambang bilangan sangat berbeda. Bilangan menyatakan suatu kuantitas, sedangkan angka adalah notasi dari bilangan tersebut.

Salah satu kompetensi yang harus dimiliki oleh peserta didik RA adalah mampu mengikuti pendidikan selanjutnya dengan kesiapan yang optimal sesuai dengan tuntutan yang berkembang dalam masyarakat.Kemampuan dasar yang dikembangkan di TK meliputi kemampuan bahasa, fisik/motorik, seni dan kemampuan kognitif.

Pengembangan kemampuan kognitif bertujuan meningkatkan kemampuan berpikir anak.Pada kemampuan kognitif tersebut, anak diharapkan dapat mengenal konsep sains dan matematika sederhana. Kegiatan pembelajaran matematika pada anak diorganisir secara terpadu melalui tema-tema pembelajaran yang paling dekat dengan konteks kehidupan anak dan pengalaman-pengalaman riil. Guru dapat menggunakan media papan flanel dalam pembelajaran yang memungkinkan anak bekerja dan belajar secara individual, kelompok dan juga klasikal.

Penggunaan media pada kegiatan pembelajaran matematika anak usia dini, khususnya dalam pengenalan konsep bilangan bertujuan mengembangkan pemahaman anak terhadap bilangan dan operasi bilangan dengan benda-benda kongkrit sebagai pondasi yang kokoh pada anak untuk mengembangkan kemampuan matematika pada tahap selanjutnya.

$$
\text { Pada pengembangan kognitif }
$$

khususnya pada pengelaman konsep 
bilangan, guru memberikan perintah kepada anak agar mengambil majalah dan pensil masing-masing. Selanjutnya guru memberikan contoh kepada anak untuk menghitung jumlah benda yang terdapat pada majalah dan mengisinya dengan bilangan yang sesuai dengan jumlah benda tersebut pada kolom yang telah disediakan.

Setelah anak mengerti, guru menyuruh anak untuk mengerjakanya sendiri. Hal ini merupakan salah satu penyebab rendahnya kemampuan anak dalam mengenal konsep lambang bilangan di TK RA Budi Rahmah Kendari. Sebagai indikator rendahnya kemampuan anak di TK tersebut, dapat dilihat bahwa dari 16 anak kelompok A. Menurut pengamatan yang dilakukan oleh peneliti di RA Budi Rahmah khususnya dalam mengenal lambang bilanga, sebagian besar anak masih kesulitan menunjukan lambang bilangan, anak masih berbalik balik menyebutkan dan menunjukan lambang bilangan satu dan yang lain.

Education Association (NEA) (dalam Fadillah 2010: 206) mengartikan media sebagai benda yang dapat dimanipulasi, dilihat, didengar, dibaca atau dibicarakan beserta instrumen yang dipergunakan, baik dalam kegiatan belajar mengajar yang dapat mempengaruhi efektivitas program instruksional.

Menurut Sadiman (2011: 48) papan flanel adalah media grafis yang efektif sekali untuk menyajikan pesan-pesan tertentu kepada sasaran tertentu pula. Papan berlapis kain flanel ini dapat dilipat sehingga praktis.

\section{METODE}

Jenis penelitian yang akan digunakan dalam penelitian ini adalah Penelitian Tindakan Kelas(PTK) atau biasa disebut (Classroom Action Research). Penelitian tindakan kelas adalah penelitian yang dilakukan guru di dalam kelasnya sendiri melalui kegiatan refleksi diri, untuk memperbaiki kinerjanya sebagai guru, sehingga hasil belajar anak didik menjadi meningkat. Arikunto (2010: 135) menyatakan bahwa penelitian tindakan kelas (classroom action research) adalah penelitian yang dilakukan oleh guru ke kelas atau di sekolah tempat ia mengajar dengan penekanan pada penyempurnaan atau peningkatan proses dan praksis pembelajaran.

Subjek penelitian adalah Anak Usia Dini Kelompok A RA Budi Rahmah Kendari. Tahun Pelajaran 2017/2018, yang berjumlah 16, terdiri dari 7 anak laki-laki dan 9 anak perempuan. Dan objek penelitiannya adalah mengenal lambang bilangan dengan media papan flanel.

Adapun faktor-faktor yang diteliti dan diamati dalam penelitian ini adalah sebagai berikut: Faktor guru, aktivitas mengajar guru, faktor anak, aktivitas belajar dan hasil belajar anak dalam mengikuti kegiatan pembelajaran, dan hasil belajar anak tentang peningkatan kemampuan kognitif anak melalui kegiatan pengelompokkan benda.

Pengumpulan data dalam penelitian ini dihimpun melalui hasil observasi, dokumentasi dan wawancara. 1). Observasi adalah suatu teknik yang dapat dilakukan guru untuk mendapatkan berbagai informasi atau data tentang peremabangan dan permasalahan anak. Melalui pengamatan, guru dapat mengetahui perkembangan yang terjadi pada anak dalam kurun waktu tertentu (Wahyudin dan Mubiar, 2011:59). 2). Observasi dilakukan oleh guru Kelompok B sebagai observer dengan menggunakan lembar observasi. Penggunaan lembar observasi ini untuk melihat proses pelaksanaan pembelajaran yang dilaksanakan oleh guru ketika melakukan kegiatan pengelompokkan benda untuk meningkatkan kemampuan kognitif anak. Dokumentasi yaitu mencari data mengenai hal-hal atau variable yang berupa catatan, transkrip, buku, surat kabar, majalah, prasasti, notulen rapat, lengger, agenda dan sebagainya (Arikunto, 2010: 274). 3). Dokumentasi ini berupa foto guru/peneliti pada saat proses meneliti sebagai bukti dalam melakukan kegiatan penelitian di lapangan. Wawancara adalah suatu tehnik pengumpulan data yang dapat dilakukan guru untuk mendapatkan informasi tentang perkembangan dan permasalahan anak dengan cara melakukan percakapan langsung, baik dengan anak maupun orang tua.

Analisis data merupakan cara yang dilakukan untuk mengetahui keefektifan suatu metode dalam kegiatan pembelajaran (Aqib, 2009:203). Pengelolaan data dalam penelitian ini disesuaikan dengan teknik penilaian di TK yaitu dengan menggunakan tanda sebagai berikut: Belum Berkembang $(\mathrm{BB})=*$, Mulai Berkembang $(\mathrm{MB})=* *$, Berkembang Sesuai Harapan $=* * *$, Berkembang Sangat Baik $=* * * *$ 
(Depdiknas, 2004: 26).

Dari segi indikator hasil, tindakan dikatakan berhasil apabila anak didik telah mencapai nilai berkembang sesuai harapan (BSH) dan berkembang sangat baik (BSB) minimal $75 \%$ baik secara individual maupun klasikal.

\section{HASIL DAN PEMBAHASAN}

Hasil penelitian ini menunjukkan adanya peningkatan dari pada kemampuan anak mengenal lambang bilangan melalui media papan flanel dengan perolehan persentase aktivitas belajar anak meningkat, di mana siklus I memperoleh persentase sebesar $60 \%$ atau 9 orang anak didik dan siklus II meningkat menjadi $80 \%$ atau 12 orang anak didik. Persentase aktivitas mengajar guru juga meningkat dari siklus I yaitu $67 \%$ atau 10 aspek yang dicapai dan aktivitas mengajar guru sikus II meningkat menjadi 93\% 14 aspek yang dicapai dari 15 aspek yang diamati.

Kemampuan anak dalam mengenal lambing bilangan juga mengalami peningkatan. Pada siklus I mengalami peningkatan dari $31 \%$ mencapai $56 \%$ dan pada siklus II mengalami peningkatan dari $56 \%$ mencapai $81 \%$.

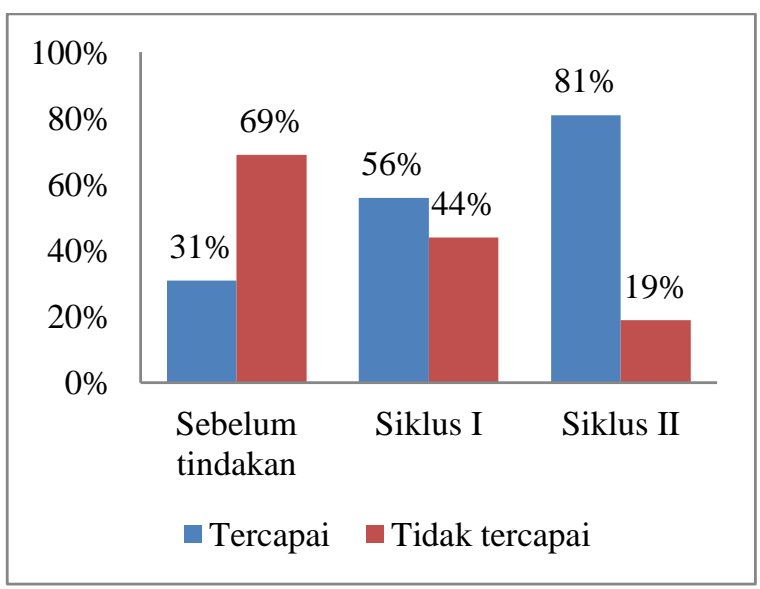

Gambar 1. Histogram Hasil Analisis Meningkatkan Kemampuan Anak Mengenal Lambang Bilangan

Selama kegiatan penelitian berlangsung, data hasil temuan yang diperoleh sebagaimana dideskripsikan pada halaman sebelumnya, dapat diasumsikan bahwa kegiatan pembelajaran dalam meningkatkan kemampuan anak mengenal lambang bilangan melalui media papan flanel yang dirancang, disusun dan dilaksanakan secara baik dan optimal oleh peneliti yang berkolaborasi dengan guru kelompok A pada setiap pertemuan Siklus I dan Siklus II sangat memberikan manfaat pada anak didik dengan pengalaman langsung dan konkret, serta kemampuan anak mengenal lambang bilangan menunjukan peningkatan terlihat dari hasil yang diperoleh anak selama mengikuti proses pembelajaran.

Jika dilihat dari pemahaman anak didik mulai dari pelaksanaan Siklus I sebesar 56\%, dibandingkan pada tahapan observasi awal/prasiklus penelitian hanya mencapai $31 \%$ dan pada tindakan Siklus II mencapai persentase sebesar $81 \%$, hal ini menunjukan hasil yang lebih baik dari sebelumnya, karena dari segi indikator hasil belajar untuk anak didik yang ditetapkan telah tercapai yaitu minimal $75 \%$ maka penelitian ini dapat dihentikan.

\section{KESIMPULAN DAN SARAN}

\section{Kesimpulan}

Berdasarkan hasil penelitian yang dilakukan di RA Budi Rahmah Kendari pada kelompok A selama dua siklus, maka dapat disimpulkan bahwa meningkatkan kemampuan anak mengenal lambang bilangan melalui media papan flanel di kelompok A RA Budi Rahmah Kendari dengan jumlah anak didik 16 orang yang terdiri dari 7 orang anak laki-laki dan 9 orang anak perempuan mengalami peningkatan.

\section{Saran}

Peneliti menyarankan hal-hal diantaranya: (1) diharapkan kepada guru, dalam pelaksanaan pembelajaran hendaknya mempertimbangkan materi, media, dan strategi yang tepat untuk anak didik dan guru dituntut untuk selalu kreatif dan inovatif dalam melaksanakan kegiatankegiatan yang dapat meningkatkan seluruh aspek perkembangan anak; (2) bagi sekolah, diharapkan dapat menuntut tenaga pendidik menjadi guru yang kreatif, inovatif dalam pengembangan kegiatan-kegiatan pembelajaran untuk anak sesuai dengan tahap perkembangan dan kebutuhan anak.

\section{DAFTAR PUSTAKA}

Aqib, Zaenal, dkk. 2009. Penelitian Tindakan Kelas untuk Guru SD, SLB, TK. Bandung: Yrama Widya.

Arikunto, Suharsimi 2010. Prosedur Penelitian Suatu Pendekatan Praktek. Jakarta: Rineka Cipta. 
Depdiknas. 2004. Pedoman Penilaian di Taman Kanak-Kanak. Jakarta: Depdiknas.

Depdiknas. 2009. Permendikna No. 58. Tentang Standar Tingkat Pencapaian Perkembangan Anak. Jakarta: Depdiknas.

Fadillah, M. 2010. Desaign Pembelajaran Anak Usia Dini. Jakarta: Kencana

Sadiman, Arief dkk. 2005. Media pendidikan,Jakarta:Raja Grafindo Persada.

Susanto, Ahmad. 2011 . Perkembangan Anak Usia Dini. Jakarta : Kencana 